\title{
Characteristics and Distribution of High- and Low-Affinity Alpha Bungarotoxin Binding Sites in the Rat Hypothalamus
}

\author{
R. B. Meeker, K. M. Michels, M. T. Libber, and J. N. Hayward \\ Department of Neurology and Neurobiology Curriculum, University of North Carolina, Chapel Hill, North Carolina \\ 27514
}

\begin{abstract}
When binding of ${ }^{125}$ I-alpha bungarotoxin ( $\left.{ }^{125} \mathrm{I}-\alpha \mathrm{BTX}\right)$ to hypothalamic membranes is observed over a wide range of concentrations, 3 binding sites can be identified, with estimated equilibrium dissociation constants $\left(K_{d} s\right)$ of $4.1 \times 10^{-11} \mathrm{M}, 6.2 \times$ $10^{-10} \mathrm{M}$, and $9.1 \times 10^{-7} \mathrm{M}$ for high-, low-, and very-low-affinity interactions, respectively. The densities of the high- and lowaffinity sites were similar at 14-21 $\mathrm{fmol} / \mathrm{mg}$ protein, whereas the very-low-affinity site had approximately $1000 \times$ greater capacity. Association and dissociation kinetics predicted a biphasic binding reaction, with association rate constants of $1.38 \times$ $10^{8} \mathrm{M}^{-1} \mathrm{~min}^{-1}$ and $7.53 \times 10^{7} \mathrm{M}^{-1} \mathrm{~min}^{-1}$ and dissociation rate constants of $5.23 \times 10^{-3} \mathrm{~min}^{-1}$ and $1.80 \times 10^{-3} \mathrm{~min}^{-1}$. The presence of $\mathrm{Na}^{+}$inhibited the binding of ${ }^{125} \mathrm{I}-\alpha \mathrm{BTX}$ with a halfmaximally effective concentration of $22 \mathrm{mM}$. This decrease in binding was associated with the observation of a single binding site with a $K_{d}$ of $4.3 \times 10^{-10} \mathrm{M}$ and a density of $12.1 \mathrm{fmol} / \mathrm{mg}$ protein. In competition binding experiments, $\alpha B T X$, curare, nicotine, and quinacrine were the most potent competitors. Acetylcholine competed with ${ }^{125} \mathrm{I}-\alpha \mathrm{BTX}$ binding at 2 sites with estimated affinities of $3.6 \times 10^{-8}$ and $7.4 \times 10^{-5} \mathrm{M}$. In the rostral hypothalamus, high-affinity binding of ${ }^{125} \mathrm{I}-\alpha$ BTX was localized to the region of the supraoptic nucleus, paraventricular nucleus, suprachiasmatic nucleus, and the nucleus circularis complex. Within magnocellular regions, binding was closely associated with neurophysin-immunoreactive neurons and processes, while in the region of the suprachiasmatic nucleus, the binding was in a perinuclear region surrounding parvocellular neurophysinimmunoreactive neurons.
\end{abstract}

It is now well recognized that the central nervous system possesses an alpha bungarotoxin-binding protein that is biochemically and pharmacologically similar to the nicotinic acetylcholine receptor (nAChR) of electric eel and muscle (Conti-Tronconi et al., 1985; Dolly and Barnard, 1984; Lowy et al., 1976; Morley, 1981; Oswald and Freeman, 1981). The binding of ${ }^{125} \mathrm{I}$-alphabungarotoxin ( ${ }^{125} \mathrm{I}-\alpha \mathrm{BTX}$ ) shows selectivity for ACh-sensitive neurons in vitro (Carbonetto et al., 1978; Chalazonitis et al., 1974; Greene et al., 1973), is associated with synaptosomes (Salvaterra et al., 1975) and can be localized to the postsynaptic region (Hunt and Schmidt, 1978a; Lentz and Chester, 1977; Marshall, 1981; Smolen, 1983; Vogel et al., 1977). A reliable pattern of ${ }^{125 I-\alpha B T X}$ binding has been observed in the brain,

\footnotetext{
Received June 27, 1985; revised Nov. 15, 1985; accepted Dec. 30, 1985.

This research was supported, in part, by NIH Javits Award NS-13411, USPHS GRSA FR-05406, a Neurobiology Training Grant, a UNC Faculty Development Award, and a UNC Medical Faculty Grant. The authors wish to express their sincere thanks to Ms. Donna Cronce for her valuable assistance in the development of techniques and the collection of data for these experiments. A preliminary report of portions of this work has been presented (Meeker et al., 1984).

Correspondence should be sent to Dr. R. B. Meeker, Department of Neurology, 781 Clinical Sciences Building 229H, University of North Carolina, Chapel Hill, NC 27514.

Copyright $\subset$ () 1986 Society for Neuroscience 0270-6474/86/071866-10\$02.00/0
}

the highest overall concentration of sites generally being in the hypothalamus (Hunt and Schmidt, 1978b; Marks and Collins, 1982; Morley et al., 1977; Segal et al., 1978). Various affinities for the binding of ${ }^{125} \mathrm{I}-\alpha \mathrm{BTX}$ to brain membranes have been reported; they range from equilibrium (or kinetic) dissociation constants $\left(K_{\mathrm{d}}\right)$ as low as $0.4-3 \times 10^{-10} \mathrm{M}$ (Lukas, 1984b; Marks and Collins, 1982; Morley et al., 1977; Salvaterra and Mahler, 1976; Schmidt, 1977; Wang et al., 1978) to intermediate values of $1-5 \times 10^{-9} \mathrm{M}$ (Lukas, 1984a, b; Patrick and Stallcup, 1977a; Salvaterra et al., 1975), and finally to the high values of $1-40 \times$ $10^{-8}$ м (Lukas, 1984b; Salvaterra, et al., 1975). Each of these sites has nAChR-like pharmacology. Given these results, it is not surprising that several investigators have suggested the presence of multiple binding sites for ${ }^{125} \mathrm{I}-\alpha \mathrm{BTX}$ in the central nervous system (Lukas, 1984b; Morley et al., 1983; Schmidt, 1977).

The above data from binding analyses provide a striking contrast to those experiments in which $\alpha \mathrm{BTX}$ has becn unable to block the functional activation of the $\mathrm{nAChR}$ in spinal cord (Duggan et al., 1976), sympathetic ganglion (Chou and Lee, 1969), and PC12 cells (Patrick and Stallcup, 1977b). Efforts to clarify such discrepancies by precipitating the ${ }^{125}$ I- $\alpha$ BTX-binding protein with monoclonal antibodies to the purified $\mathrm{nAChR}$ have yielded mixed results, with some investigators successfully immunoprecipitating the ${ }^{125} \mathrm{I}-\alpha \mathrm{BTX}$-binding protein (Block and Billiar, 1979; Dolly and Barnard, 1984), while others have been unsuccessful (Patrick and Stallcup, 1977b). Thus, the precise identity of the $\alpha \mathrm{BTX}$-binding protein remains questionable. This issue is particularly important for the understanding of the role of the cholinergic network which is thought to control the release of vasopressin or oxytocin. The release of vasopressin is well recognized as being induced by nicotinic cholinergic agonists (Volle and Koelle, 1975), and the system that mediates this response is probably contained within the rostral hypothalamus (Sladek, 1983). Further support for this possibility is provided by the high binding of ${ }^{125} \mathrm{I}-\alpha \mathrm{BTX}$ in the hypothalamus (Marks and Collins, 1982; Morley et al., 1977; Segal et al., 1978) and particularly the supraoptic nucleus (NSO) of the hypothalamus (Hunt and Schmidt, 1978b; Polz-Tejera et al., 1975; Silver and Billiar, 1976). Electrophysiological evidence indicates that the cells responsive to nicotinic cholinergic agonists may be the same as or similar to the cells that synthesize vasopressin in the NSO of the hypothalamus (Arnauld et al., 1983; Barker et al., 1971; Bioulac et al., 1978; Gahwiler and Dreifuss, 1980; Sakai et al., 1974). Thus, a nicotinic cholinergic synapse within the NSO may be an important link in the neural mechanisms that control the secretion of vasopressin.

In an effort to evaluate the significance of the binding of ${ }^{125} \mathrm{I}-$ $\alpha$ BTX in the NSO and the possible presence of nAChRs, we have characterized pharmacologically the binding of ${ }^{125} \mathrm{I}-\alpha \mathrm{BTX}$ in the hypothalamus. A procedure for combining receptor autoradiography and immunocytochemistry on a single free-floating section allowed assessment of the codistribution of neuro- 
physin-immunoreactive neurons and $\alpha \mathrm{BTX}$ binding sites.

Three ${ }^{125} \mathrm{I}-\alpha \mathrm{BTX}$ binding sites, with $K_{\mathrm{d}} \mathrm{s}$ ranging from $4.1 \times$ $10^{-11}$ to $4.0 \times 10^{-7} \mathrm{M}$, can be discriminated in the brain. The high-affinity sites have nicotinic cholinergic pharmacology, a half-time on the receptor of 2-6 hr, and are sensitive to the cation concentration in the buffer. These high-affinity sites are localized to the region of the NSO, suprachiasmatic nucleus (NSC), paraventricular nucleus (NPV), and nucleus circularis (NC). A high correlation of this binding distribution with neurophysin-immunoreactive magnocellular neurons suggests that these binding sites may have a special relevance for the functional organization of the vasopressin/oxytocin neurosecretory system.

\section{Materials and Methods}

\section{Materials}

Monoiodinated ${ }^{125}$ I- $\alpha$ BTX was obtained from New England Nuclear at an initial specific activity of $16.5-17.6 \mu \mathrm{Ci} / \mu \mathrm{g}(261-279 \mathrm{cpm} / \mathrm{fmol})$. All cholinergic ligands were obtained from Sigma. Normal goat serum was purchased from Antibodies Incorporated. Tetramethylrhodamine isothiocyanate-conjugated goat anti-rabbit IgG (TRITC-GAR, lot no. 15967) was purchased from Cappel. The specific RN4 neurophysin antibody (Reaves et al., 1983; Sokol et al., 1976) was the generous gift of Dr. Alan Robinson, University of Pittsburgh (Grant AM-16166). Other materials were of reagent or comparable quality and were from standard sources.

\section{Preparation of membranes for ${ }^{125} I-\alpha B T X$ binding}

Male Sprague-Dawley rats were lightly anesthetized with sodium pentobarbital $(30 \mathrm{mg} / \mathrm{kg})$. Each rat was then killed by decapitation; the brain was rapidly removed and immersed in ice-cold $0.32 \mathrm{M}$ sucrose. The hypothalamus and brain stem were dissected from the brain on ice (Hayward et al., 1983). Washed membranes from each region were prepared by homogenizing the tissue in $10 \mathrm{vol}$ of $0.32 \mathrm{M}$ sucrose. The resulting homogenate was centrifuged at $600 \times g$ for $10 \mathrm{~min}$, the pellet discarded, the membrane suspension diluted to a volume of $40 \mathrm{ml}$ with assay buffer ( $10 \mathrm{~mm}$ phosphate buffer, $1 \mathrm{~mm}$ EDTA, $0.1 \mathrm{~mm}$ phenylethylsulfonyl flouride, $0.02 \%$ sodium azide) and centrifuged at $39,000 \times$ $g$ for $20 \mathrm{~min}$. The resulting pellet was resuspended in $40 \mathrm{ml}$ assay buffer and again centrifuged at $39,000 \times \mathrm{g}$. After a total of 3 washes, the tissue was resuspended in assay buffer at a concentration of $100-200 \mathrm{mg} / \mathrm{ml}$ and aliquots stored frozen at $-80^{\circ} \mathrm{C}$. Binding of ${ }^{125} \mathrm{I}-\alpha \mathrm{BTX}$ to the frozen membranes did not differ from that to fresh tissue, and remained stable for at least 1 month.

\section{Characterization of ${ }^{125} I-\alpha B T X$ binding}

Washed membranes were diluted in assay buffer at concentrations ranging from 5 to $50 \mathrm{mg}$ wet $\mathrm{wt} / \mathrm{ml}$. A $400 \mu \mathrm{l}$ aliquot of membranes (2-20 $\mathrm{mg}$ wet weight) was added to polypropylene tubes containing 6-1000

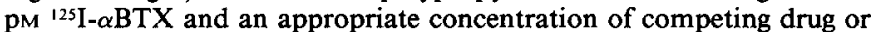
buffer. Final assay volume was $0.5 \mathrm{ml}$. Tubes were incubated at $22^{\circ} \mathrm{C}$ for $2.5 \mathrm{hr}$. The reaction was terminated by adding $10 \mathrm{ml}$ of wash buffer

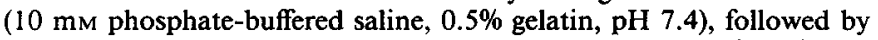
rapid filtration through Schleicher and Schuell no. 30 glass fiber filters. Each filter was washed twice with $100 \mathrm{ml}$ of wash buffer. The dry filters were transferred to $13 \times 100 \mathrm{~mm}$ tubes and counted in a Tracor gamma counter at an efficiency of $85-90 \%$. This procedure was effective in reducing any nonspecific binding of ${ }^{125}$ I- $\alpha$ BTX to the glass fiber filters to less than $1 \%$ of the total counts added at the highest ligand concentrations. These filter blanks were constant within each experiment and were subtracted from the total binding values. Attempts to reduce nonspecific filter binding with other compounds, including serum albumins, poly-L-lysine, $0.5 \mathrm{~m} \mathrm{NaCl}$, and Prosil (Harden et al., 1983), were less effective. Nonspecific binding to tissue ranged from 10 to $50 \%$ of the total binding, depending on the concentration of ${ }^{125} \mathrm{I}-\alpha \mathrm{BTX}$ in the assay. Both total and nonspecific binding of ${ }^{125} \mathrm{I}-\alpha \mathrm{BTX}$ to rat brain membranes were found to be unaffected by $\mathrm{pH}$ in the range of 7.0-8.2. Results obtained with the filtration binding assay were the same as those of experiments utilizing a centrifugation assay protocol. Protein determinations were made on samples of the tissue homogenates according to the method of Lowry et al. (1951).
A protocol similar to the above was followed for the binding of ${ }^{125} \mathbf{I}$ $\alpha$ BTX to $50 \mu \mathrm{m}$ sections of hypothalamus, with the following exceptions: (1) Sections were washed in an excess of assay buffer and then transferred to a 24-well tissue culture plate containing ${ }^{125} I-\alpha B T X$ in a final assay volume of $1 \mathrm{ml}$. (2) Binding was terminated by transferring the sections through 3 successive 2 min washes in $2 \mathrm{ml}$ of wash buffer and, finally, into a $13 \times 100 \mathrm{~mm}$ test tube containing $0.5 \mathrm{ml}$ assay buffer. Each section was immediately counted for $1 \mathrm{~min}$ in a Tracor gamma counter and then quickly mounted onto a gelatin-chrome alum-coated glass slide and dried in preparation for autoradiography.

\section{Data analysis}

Computer analysis of the data from saturation binding and competition binding experiments was accomplished by using either a Gauss-Newton or Marquart nonlinear least-squares regression program that required a minimum of approximately 15 data points per curve. Since highly accurate values are difficult to obtain with nonspecific binding and other potential sources of variability exceeding $10 \%$ of the total binding, such values should be considered estimates, particularly for the low-affinity site. Error values for replicate determinations of $K_{d} s$ were $\pm 31 \%$ and $\pm 102 \%$ for the high- and low-affinity sites, respectively. Estimates for both the high- and low-affinity $B_{\max }$ values were replicated to within $\pm 17 \%$. The saturation binding nonlinear regression was based on the equation,

$$
B=\frac{B_{\max 1} \times L}{L+K_{\mathrm{d} 1}}+\frac{B_{\max 2} \times L}{L \times K_{\mathrm{d} 2}}
$$

where $B=$ total ligand specifically bound, $L=$ ligand concentration, $K_{\mathrm{dl}}=$ dissociation constant for the high-affinity site, $B_{\max 1}=$ density of the high-affinity site, $K_{\mathrm{d} 2}=$ dissociation constant for the low-affinity site, and $B_{\max 2}=$ density of the low-affinity site.

Competition binding nonlinear regression analysis was based on the equation,

$$
\begin{aligned}
\text { Fractional occupancy }= & \frac{B_{\max 1}}{B_{\mathrm{T}}} \times \frac{L}{L+I C_{50,1}} \\
& +\frac{B_{\max 2}}{B_{\mathrm{T}}} \times \frac{L}{L+I C_{50,2}}
\end{aligned}
$$

where $B_{\mathrm{T}}=$ total ligand bound, $L=$ ligand concentration, $I C_{50,1}=$ concentration of drug that inhibits half the high-affinity binding, $I C_{50,2}=$ concentration of drug that inhibits half the low-affinity binding, $B_{\max 1}=$ relative density of high-affinity sites, and $B_{\max 2}=$ relative density of lowaffinity sites.

Inhibition constants $\left(K_{\mathrm{I}} \mathrm{s}\right)$ from competition binding experiments were calculated from $I C_{50}$ values according to Cheng and Prusoff (1973):

$$
K_{1}=\frac{I C_{50}}{1+F / K_{\mathrm{d}}}
$$

where $I C_{50}=$ the concentration of drug that inhibits half the ligand binding, $F=$ the free molar concentration of the ligand, and $K_{\mathrm{d}}=$ the dissociation constant of the ligand. Conditions for competition binding were generally established such that the majority of the ligand binding was to the high-affinity site. Consequently, the high-affinity $K_{d}$ estimates were used for the calculation of the inhibition constants.

\section{Combined receptor autoradiography and neurophysin immunocytochemistry}

Male Sprague-Dawley rats were deeply anesthetized with sodium pentobarbital $(60 \mathrm{mg} / \mathrm{kg})$. The chest cavity was opened and the rat was rapidly perfused through the heart with a balanced salt solution $(50 \mathrm{ml})$ followed by $0.5 \%$ paraformaldehyde in $50 \mathrm{~mm}$ PBS $(200 \mathrm{ml}, \mathrm{pH} 7.4)$. The brain was removed, blocked, and postfixed overnight at $22^{\circ} \mathrm{C}$ in the same $0.5 \%$ paraformaldehyde solution. Free-floating $50 \mu \mathrm{m}$ sections were cut on a vibrating microtome and then processed sequentially through the following solutions: (1) $0.01 \mathrm{mM}$ PBS, pH 7.4, $5 \mathrm{~min} \times 2$, (2) $0.01 \mathrm{~m}$ PBS, $1 \%$ normal goat serum, $0.01 \%$ sodium azide, $10 \mathrm{~min}$, (3) neurophysin antibody RN4 (1:2000), 16-24 hr at $4^{\circ} \mathrm{C}$ in PBS, $1 \%$ normal goat serum, $0.01 \%$ sodium azide, (4) $2 \mathrm{ml}$ receptor-binding assay buffer, $5 \mathrm{~min}$ at $22^{\circ} \mathrm{C} \times 3,(5) 1 \mathrm{ml}$ binding assay buffer containing $10-$ 1000 pM ${ }^{125} \mathrm{I}-\alpha \mathrm{BTX}$ and TKITC-GAR (1:200), $2.5 \mathrm{hr}$ at $22^{\circ} \mathrm{C}$, and (6) $2 \mathrm{ml} \mathrm{PBS}, 2 \mathrm{~min} \times 3$. At the end of the labeling/binding procedure, 


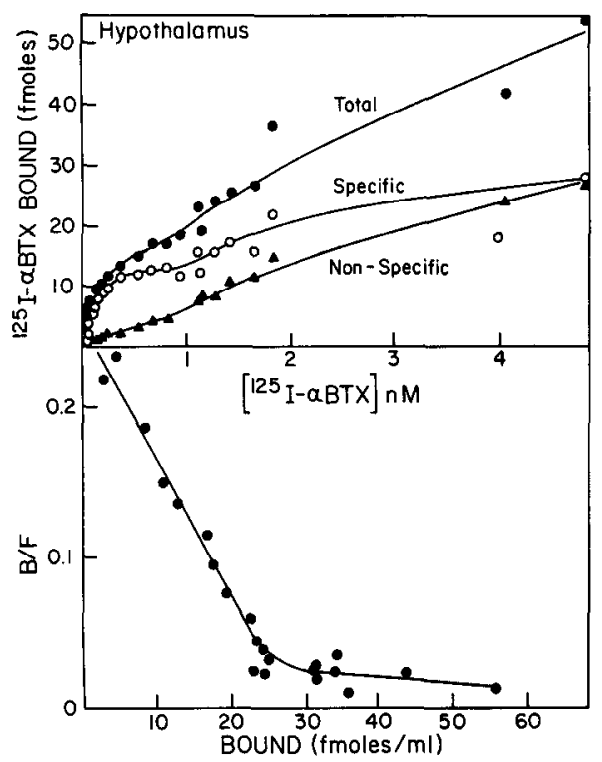

Figure 1. Saturation binding profile for the interaction of ${ }^{125} \mathrm{I}-\alpha \mathrm{BTX}$ with fresh, washed membranes from rat hypothalamus. Each assay tube, containing $360 \mu \mathrm{g}$ tissue protein, was incubated with 13-4852 pM ${ }^{125} \mathrm{I}$ $\alpha \mathrm{BTX}$ for $2.5 \mathrm{hr}$ at $22^{\circ} \mathrm{C}$. Top, Total (๑), specific (O), and nonspecific (A) binding of ${ }^{125}$ I- $\alpha$ BTX is plotted as a function of the free ${ }^{125} \mathrm{I}-\alpha \mathrm{BTX}$ concentration. Two-site analysis of the Scatchard curve for specific ${ }^{125} I-$ $\alpha \mathbf{B T X}$ binding (bottom), using a Gauss-Newton nonlinear regression curve-fitting procedure, resulted in $K_{\mathrm{d}}$ estimates of $4.1 \times 10^{-11} \mathrm{M}$ and $6.2 \times 10^{-10} \mathrm{M}$ for the high- and low-affinity sites, respectively. Estimates of $B_{\max }$ were 21.1 and $13.9 \mathrm{fmol} / \mathrm{mg}$ protein for the high- and lowaffinity sites, respectively. Nonspecific binding was determined in the presence of $10^{-5} \mathrm{M} \alpha \mathrm{BTX}$.

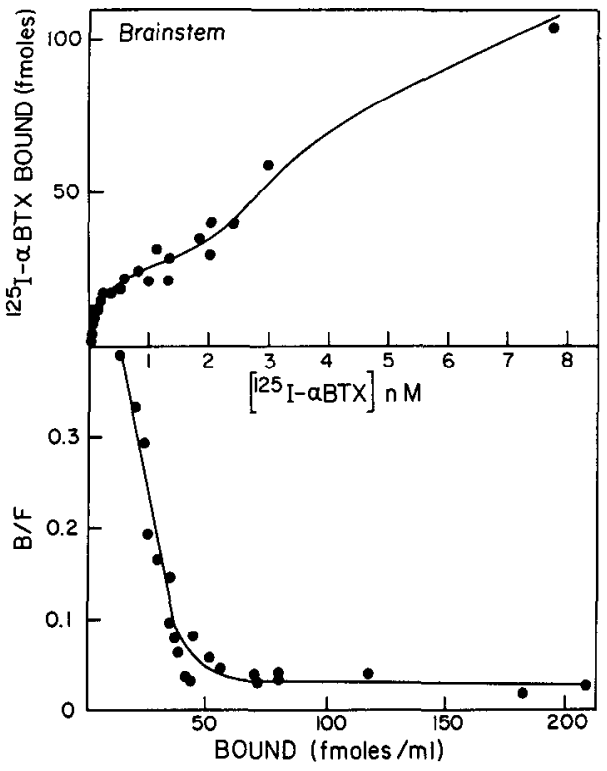

Figure 2. Saturation binding profile for the interaction of ${ }^{125} \mathrm{I}-\alpha \mathrm{BTX}$ with washed membranes prepared from rat brain stem. Specific binding of ${ }^{125} \mathrm{I}-\alpha \mathrm{BTX}$ to $820 \mu \mathrm{g}$ tissue protein is plotted as a function of free ligand concentration from 6 to $7721 \mathrm{pM}$ (top). Nonlinear regression analysis of the Scatchard curve (bottom) resulted in $K_{\mathrm{d}}$ estimates of $2.2 \times 10^{-11} \mathrm{M}$ and $2.8 \times 10^{-9} \mathrm{M}$ for the high- and low-affinity sites, respectively. Estimates of $B_{\max }$ were 17.6 and $25.8 \mathrm{fmol} / \mathrm{mg}$ protein. Nonspecific binding was determined in the presence of $10 \mathrm{~mm} \mathrm{ACh}$.

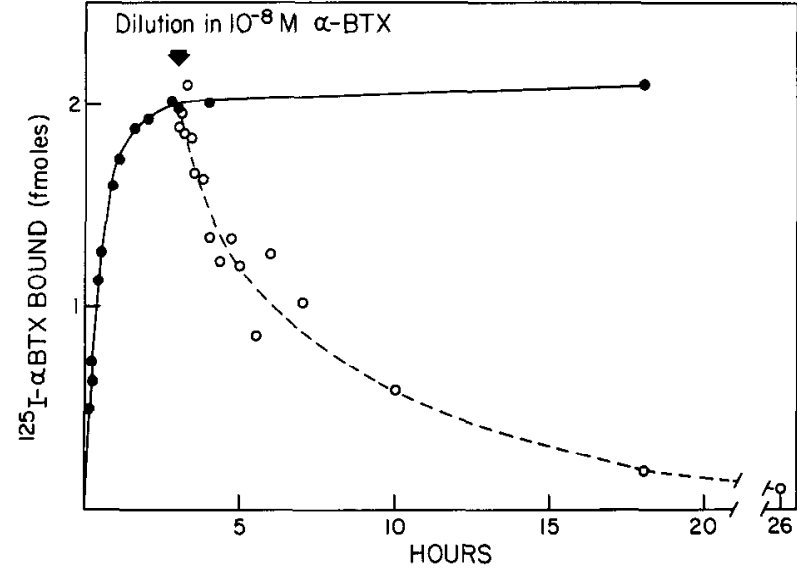

Figure 3. Time course for the association (O) and dissociation (O) of ${ }^{125} \mathrm{I}-\alpha \mathrm{BTX}$ on membranes prepared from rat brain. Tissue (338 $\mu \mathrm{g}$ protein) was incubated in $0.5 \mathrm{ml}$ assay buffer containing $182 \mathrm{pm}{ }^{125} \mathrm{I}-\alpha \mathrm{B} T \mathrm{X}$ for the times indicated. After $3 \mathrm{hr}$, membranes were diluted in 20 -fold excess assay buffer containing $10^{-8} \mathrm{M} \alpha \mathrm{BTX}$. The dissociation process was terminated at the indicated times by rapid filtration and washing of the membranes.

each section was counted and prepared for autoradiography, as described above. Nonspecific binding values determined in the presence of excess $d$-tubocurarine, nicotine, or acetylcholine were all found to give comparable results (approximately $20-40 \%$ nonspecific binding). The wet weight of the sections used for this assay averaged $0.580 \pm$ $0.052 \mathrm{mg}$ and contained approximately $52.7 \mu \mathrm{g}$ of protein.

\section{Autoradiography}

Slides containing $50 \mu \mathrm{m}$ sections of hypothalamus were dipped in Kodak NTB-2 emulsion at $45^{\circ} \mathrm{C}$ in total darkness. The emulsion-coated slides were allowed to dry at room temperature and were then transferred to sealed, desiccated slide boxes, where they were exposed at $4^{\circ} \mathrm{C}$ for a period of 14-28 d (2000-4000 $\mathrm{cpm} \times \mathrm{d})$. At the end of the exposure period, the emulsion was developed in Kodak D-19 (1:1) for 4 min, washed in distilled water for $10 \mathrm{sec}$, and fixed in Kodak fixer for $5 \mathrm{~min}$. Sections were examined unstained or lightly counterstained in Pyronin $Y$ according to the following procedure: (1) Distilled water, 5 dips. (2) Citric acid-sodium phosphate buffer, $20 \mathrm{~mm}, \mathrm{pH} 5.6,5$ dips. (3) $0.2 \%$ Pyronin $Y$ in citrate-phosphate buffer, 5 dips. (4) Citrate-phosphate buffer, 5 dips. (5) Distilled water, 5 dips $\times 2$. The sections were then dehydrated in $50,70,80,95$, and $100 \%$ ethanol ( 2 min each), cleared in xylene, and coverslipped with Permount. The distribution of silver grains was examined and photographed on a Leitz Orthoplan microscope under both bright- and dark-field illumination.

\section{Results}

\section{Binding of low concentrations of ${ }^{125} I-\alpha B T X$ to rat brain membranes}

Binding of ${ }^{125} \mathrm{I}-\alpha \mathrm{BTX}$ to membranes from rat hypothalamus is linear over a range of at least $0.5-0.6 \mathrm{mg}$ protein (data not shown). Saturation binding of ${ }^{125}$ I- $\alpha$ BTX to hypothalamic membranes is illustrated in Figure 1. The binding profile is complex, appearing to approach saturation at $4 \times 10^{-10} \mathrm{M}^{125} \mathrm{I}-\alpha \mathrm{BTX}$ and then increasing again. A Scatchard analysis (Fig. 1, bottom) of the data indicated the presence of 2 binding sites. Nonlinear regression analysis (regression lines not shown) identified a highaffinity ${ }^{125} \mathrm{I}-\alpha \mathrm{BTX}$ binding site, with a $K_{\mathrm{d}}$ of $4.1 \times 10^{-11} \mathrm{M}$ and a maximum density $\left(B_{\mathrm{max}}\right)$ of $21.1 \mathrm{fmol} / \mathrm{mg}$ protein, and a lowaffinity site with a $K_{\mathrm{d}}$ of $6.2 \times 10^{-10} \mathrm{M}$ and a $B_{\max }$ of $13.9 \mathrm{fmol} /$ mg protein.

The characteristics of ${ }^{125} \mathrm{I}-\alpha \mathrm{BTX}$ binding to membranes prepared from brain stem, illustrated in Figure 2, are qualitatively and quantitatively similar to those of membranes from hypothalamus. Two-site analysis of the biphasic binding profile predicted $K_{\mathrm{d}} \mathrm{s}$ of $2.2 \times 10^{-11} \mathrm{M}$ and $2.8 \times 10^{-9} \mathrm{M}$ for the high- and 


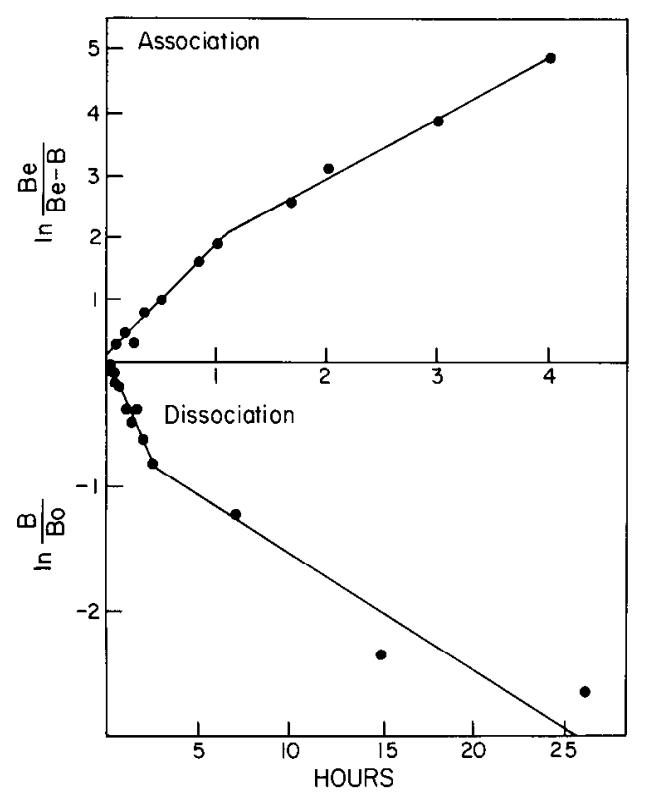

Figure 4. Transformed association and dissociation rate data from Figure 3. Top, Natural logarithmic transformation of the amount of ${ }^{125}$ I- $\alpha$ BTX bound at equilibrium $\left(B_{e}\right)$, divided by the difference between $B_{\mathrm{e}}$ and the amount bound at each time point, $B$, on the association curve, plotted as a function of time. Approximately $80 \%$ of the bound ${ }_{125} \mathrm{I}-\alpha \mathrm{BTX}$ associates as a fast component and $20 \%$ as a slower component. The estimated association rate constants from the slope of each line are $1.38 \times 10^{8} \mathrm{M}^{-1} \mathrm{~min}^{-1}$ and $7.53 \times 10^{7} \mathrm{M}^{-1} \mathrm{~min}^{-1}$ for the fast and slow components, respectively. Bottom. Natural logarithmic transformation of the amount of ${ }^{125} \mathrm{I}-\alpha \mathrm{BTX}$ bound at each time point, $B$, relative to the amount bound at the beginning of the dissociation process $\left(B_{0}\right)$. Approximately $60 \%$ of the total bound dissociates as a fast component and $40 \%$ as a slow component. Estimates of the dissociation rate constants are $5.23 \times 10^{-3} \mathrm{~min}^{-1}$ and $1.80 \times 10^{-3} \mathrm{~min}^{-1}$ for the fast and slow components, respectively.

low-affinity sites, respectively, and corresponding densities of 17.6 and $25.8 \mathrm{fmol} / \mathrm{mg}$ protein. The presence of both high- and low-affinity binding sites throughout the brain was confirmed by the observation of similar curvilinear binding profiles to the hippocampus, amygdala, septum, and cortex. The regions varied only in the density of binding sites, with the hypothalamus having the highest density. The remaining regions all exhibited similar receptor densities.

\section{Kinetics of ${ }^{125} I-\alpha B T X$ binding}

The association and dissociation of ${ }^{125} \mathrm{I}-\alpha \mathrm{BTX}$ on membranes is illustrated in Figure 3. Equilibrium is established after approximately $2.5 \mathrm{hr}$ at $22^{\circ} \mathrm{C}$ and is maintained for at least $18 \mathrm{hr}$. Dilution of the membranes in 20-fold excess assay buffer containing $10^{-8} \mathrm{M} \alpha \mathrm{BTX}$ to halt the association process initiated a relatively rapid decline in the ${ }^{125} \mathrm{I}-\alpha \mathrm{BTX}$ bound to the membranes. Analysis of the transformed data (Fig. 4) indicated the presence of a biphasic rate process for both the association and dissociation of ${ }^{25} \mathrm{I}-\alpha \mathrm{BTX}$. Association rate $\left(k_{+1}\right)$ estimates yielded values of $1.38 \times 10^{8} \mathrm{M}^{-1} \mathrm{~min}^{-1}$ and $7.53 \times 10^{7} \mathrm{M}^{-1} \mathrm{~min}^{-1}$ for the fast and slow components, respectively. Analysis of the dissociation process yielded rates of $5.23 \times 10^{-3} \mathrm{~min}^{-1}$ and $1.80 \times 10^{-3} \mathrm{~min}^{-1}$ for the fast and slow components, respectively $\left(t_{1 / 2}=132\right.$ and $385 \mathrm{~min}$, respectively). The fast component accounted for the majority of the association $(80 \%)$, whereas the slow component accounted for approximately $60 \%$ of the total dissociation.

\section{Analysis of a very-low-affinity ${ }^{125} I-\alpha B T X$ binding site}

Recently, Lukas (1984b) described a binding site for ${ }^{125} \mathrm{I}-\alpha \mathrm{BTX}$ in brain that had a $K_{\mathrm{d}}$ of $4 \times 10^{-7} \mathrm{M}$. Since a site of such low

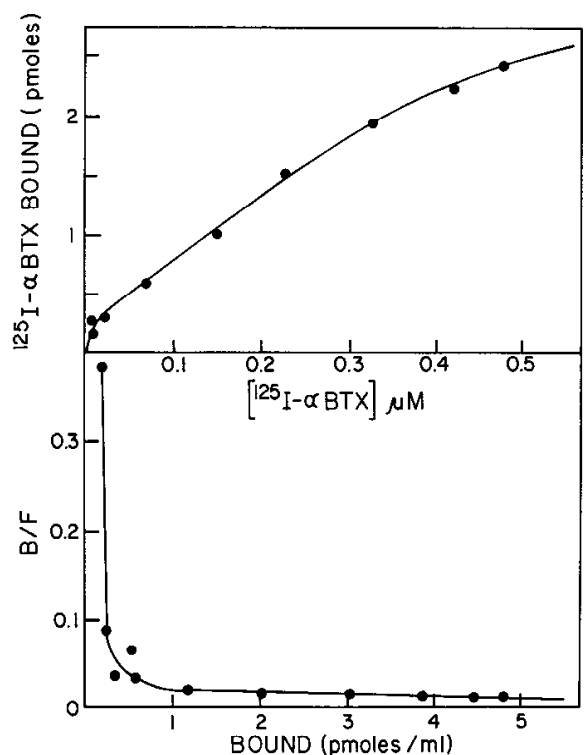

Figure 5. Very-low-affinity binding of ${ }^{125} \mathrm{I}-\alpha \mathrm{BTX}$. Top, Saturation binding isotherm for the interaction of $0.54-476 \mathrm{~nm}$ 125I- $\alpha$ BTX $(2 \mathrm{cpm} /$ fmol) with $240 \mu \mathrm{g}$ of brain membrane protein. Specific binding is plotted as a function of ${ }^{125} \mathrm{I}-\alpha \mathrm{BTX}$ concentration. Bottom, Scatchard analysis of the data illustrates binding of ${ }^{125} \mathrm{I}-\alpha \mathrm{BTX}$ to 2 sites. The very-lowaffinity site has an estimated $K_{\mathrm{d}}$ of $910 \mathrm{nM}$ and a density of $28.1 \mathrm{pmol} /$ $\mathrm{mg}$ protein. Nonspecific binding was defined as binding in the presence of $5 \mathrm{~mm} \mathrm{ACh}$ and varied from 24 to $42 \%$ of total binding.

affinity could not be detected using our standard assay conditions, we reduced the specific activity of our ${ }^{125} \mathrm{I}-\alpha \mathrm{BTX}$ to $1-2$ $\mathrm{cpm} / \mathrm{fmol}$ by adding unlabeled $\alpha \mathrm{BTX}$. This specific activity was too low to measure the high-affinity binding of ${ }^{125} \mathrm{I}-\alpha \mathrm{BTX}$. A saturation binding analysis (Fig. 5) confirmed the presence of a very-low-affinity binding site with a $K_{\mathrm{d}}$ of $9.1 \times 10^{-7} \mathrm{M}$ and a $B_{\max }$ of $28.1 \mathrm{pmol} / \mathrm{mg}$ protein. Some binding to the low-affinity ${ }^{125} \mathrm{I}-\alpha \mathrm{BTX}$ binding site was also measured under these conditions, yielding a curvilinear Scatchard plot.

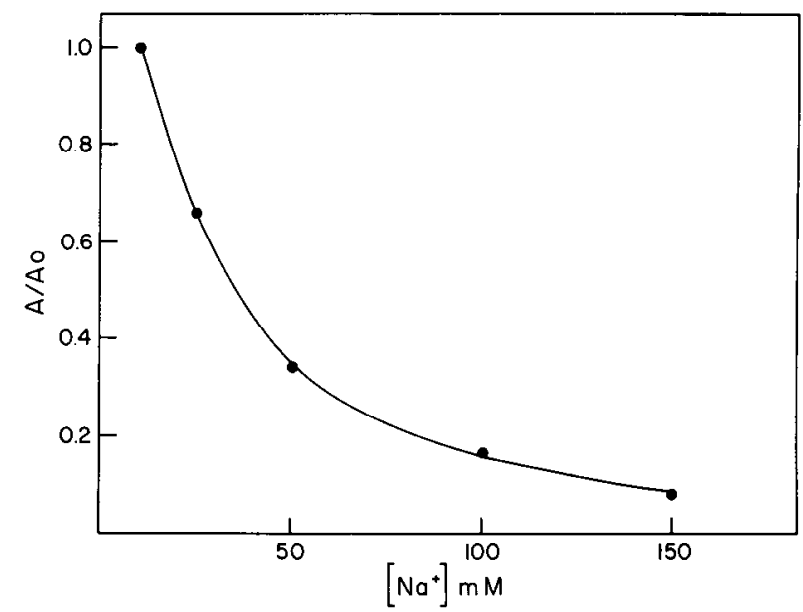

Figure 6. Inhibition of ${ }^{125} \mathrm{I}-\alpha \mathrm{BTX}$ binding as a function of increasing concentrations of $\mathrm{Na}^{+}$in the assay buffer. Brain membranes $(480 \mu \mathrm{g}$ protein) were incubated in assay buffer containing $157 \mathrm{pM}^{225} \mathrm{I}-\alpha \mathrm{BTX}$ and the indicated concentration of $\mathrm{Na}^{+}$as the chloride salt. A total of $2.23 \mathrm{fmol}$ of ${ }^{125} \mathrm{I}-\alpha \mathrm{BTX}$ was specifically bound in assay buffer $\left(A_{0} ; 10\right.$ $\mathrm{mM} \mathrm{Na} \mathrm{Na}^{+}$. The amount of ${ }^{125}$ I- $\alpha \mathrm{BTX}$ specifically bound in the presence of additional $\mathrm{Na}^{+}(A)$ relative to $A_{0}$ is plotted as a function of $\mathrm{Na}^{+}$ concentration. Nonspecific binding in the presence of $5 \mathrm{~mm}$ ACh was $29 \%$ and $70 \%$ of total binding at 10 and $150 \mathrm{mM} \mathrm{Na}^{+}$, respectively. 


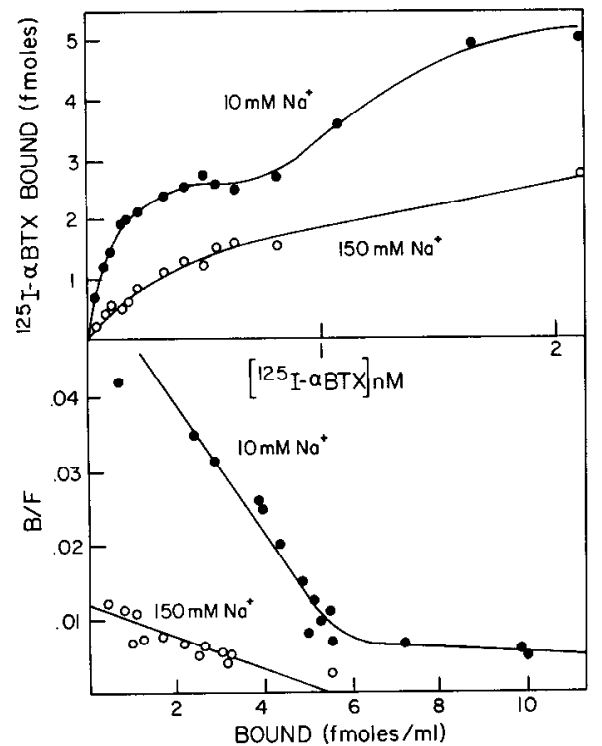

Figure 7. Saturation binding analysis of the interaction of ${ }^{125} \mathrm{I}-\alpha \mathrm{BTX}$ with brain membranes in the presence of $150 \mathrm{mM} \mathrm{Na}^{+}$. A total of 424 $\mu \mathrm{g}$ of tissue protein was incubated with 32-2136 pM ${ }^{125} \mathrm{I}-\alpha \mathrm{BTX}$ in assay buffer $(\bullet)$ or assay buffer containing $150 \mathrm{mM} \mathrm{Na}^{+}(O)$ for $2.5 \mathrm{hr}$ at $22^{\circ} \mathrm{C}$. Top, Specific binding of ${ }^{125} \mathrm{I}-\alpha \mathrm{BTX}$ is plotted as a function of free ${ }^{125} \mathrm{I}-$ $\alpha$ BTX concentration. Bottom, Scatchard analysis of the data illustrates 2 binding components in the presence of $10 \mathrm{mM} \mathrm{Na}^{+}$and a single binding component in the presence of $150 \mathrm{~mm} \mathrm{Na}$. Nonspecific binding of ${ }^{125} \mathrm{I}-$ $\alpha \mathrm{BTX}$ in the presence of $10 \mathrm{~mm}$ ACh ranged from $18 \%$ of the total counts bound at low ${ }^{125}$ I- $\alpha$ BTX concentrations to $49 \%$ of the total counts bound at high concentrations.

\section{Effects of $\mathrm{Na}^{+}$on ${ }^{125} \mathrm{I}-\alpha \mathrm{BTX}$ binding}

The presence of increasing concentrations of $\mathrm{NaCl}$ in the assay buffer progressively inhibited the binding of ${ }^{125} \mathrm{I}-\alpha \mathrm{BTX}$ (Fig. 6) with a half-maximally effective concentration of $22 \mathrm{~mm}$. The effect of $\mathrm{Na}^{+}$on the affinity of ${ }^{125} \mathrm{I}-\alpha \mathrm{BTX}$ for its binding site is illustrated in Figure 7. In $150 \mathrm{mM} \mathrm{Na}^{+}$, the specific binding of ${ }^{125}$ I $-\alpha$ BTX exhibits a saturation binding profile typical of interaction with a single site. Scatchard analysis of the data confirmed the presence of a single site with a $K_{\mathrm{d}}$ of $4.3 \times 10^{-10} \mathrm{M}$ and a maximum density of $12.1 \mathrm{fmol} / \mathrm{mg}$ protein, approximately equal

\section{Table 1. Affinity of various compounds for the $\alpha$ bungarotoxin} receptor in rat brain

\begin{tabular}{lc} 
Drug & $K_{\mathrm{I}}(\mu \mathrm{M})$ \\
\hline$\alpha$ Bungarotoxin & 0.003 \\
$d$-Tubocurarine & 0.117 \\
Nicotine & 2.1 \\
Dimethylphenylpiperazinium & 2.2 \\
Quinacrine & 3.9 \\
Ethopropazine & 27.2 \\
Substance P & 31.4 \\
Butyrlcholine & 88.5 \\
Acetylcholine & 93.0 \\
Choline & 267 \\
Arginine vasopressin & $>10$ \\
Phenylmethylsufonylfluoride & $>100$
\end{tabular}

The binding of each compound in competition with ${ }^{225} \mathrm{I}-\alpha \mathrm{BTX}$ was determined under standard assay conditions at concentrations of $149-459$ pм ${ }^{125} \mathrm{I}-\alpha \mathrm{BTX}$. Under such conditions, the number of high-affinity sites occupied, relative to lowaffinity sites, is greater than $5: 1$. Inhibition constants $\left(K_{1}\right)$ were calculated according to Cheng and Prusoff (1973). Binding that could not be inhibited by the drugs represented $24 \pm 9 \%$ of total binding.

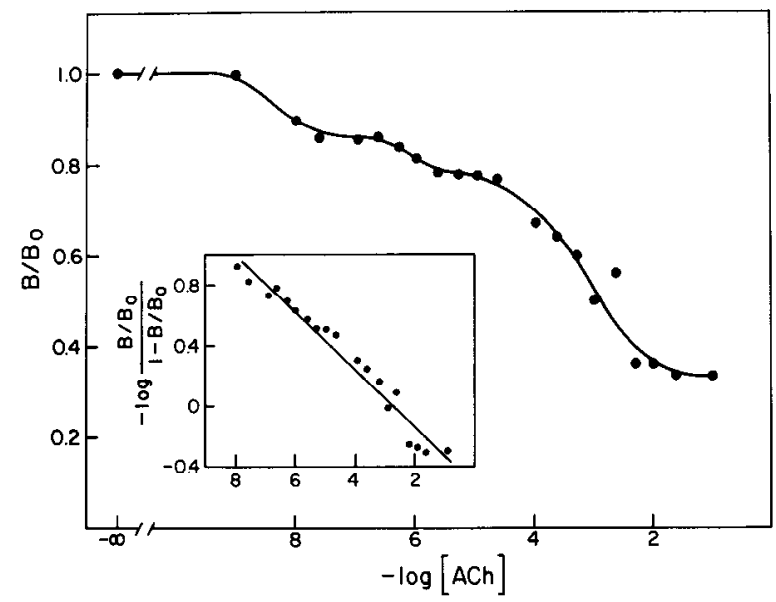

Figure 8. Competition binding curve for ACh in the presence of 517 $\mathrm{pM}^{125}$ I- $\alpha \mathrm{BTX}$. Ligand bound in the presence of varying concentrations of $\mathrm{ACh}(B)$ relative to the amount bound in the absence of added competitor $\left(B_{0} ; 750 \mathrm{cpm}\right)$ is plotted as a function of the molar ACh concentration. Hill analysis of the binding data (inset) yielded a straight line $\left(r^{2}=0.96\right)$ with a slope of -0.19 . At the highest ACh concentration, $64 \%$ of the total binding was displaced. Nonlinear regression analysis of the binding curve indicated the presence of at least 2 binding sites with apparent affinities for ACh of $3.6 \pm 2.8 \times 10^{-8} \mathrm{M}$ and $7.4 \pm 0.3 \times$ $10^{-5} \mathrm{M}$. Binding was accomplished in the presence of $10 \mu \mathrm{M}$ eserine and $1 \mu \mathrm{M}$ atropine to minimize degradation of the $\mathrm{ACh}$ and interaction with muscarinic receptors, respectively. Data represent the average of 2 experiments. SE for each data point, less than $\pm 12 \%$.

to the density $(15.2 \mathrm{fmol} / \mathrm{mg}$ protein $)$ of the high-affinity site in the presence of $10 \mathrm{mM} \mathrm{Na}$.

Comparison of the effects of the chloride salts of other monovalent cations on the binding of ${ }^{125} \mathrm{I}-\alpha \mathrm{BTX}$ revealed a similar inhibitory effect. The following order of potency was found, based on the ability to inhibit $50 \%\left(I C_{50}\right)$ of the total specific ${ }^{125} \mathrm{I}-\alpha \mathrm{BTX}$ binding in $10 \mathrm{~mm}$ assay buffer: $\mathrm{Na}^{+}, \mathrm{NH}_{4}{ }^{+}, \mathrm{Rb}^{+}(22-$

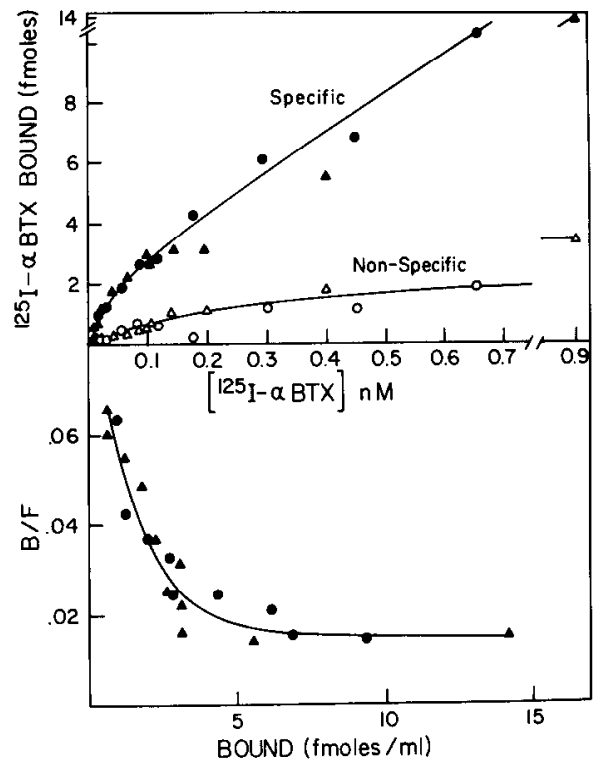

Figure 9. Concentration-dependent accumulation of ${ }^{125} \mathrm{I}-\alpha \mathrm{BTX}$ on 50 $\mu \mathrm{m}$ sections of rat hypothalamus. Hypothalamic sections containing approximately $53 \mu \mathrm{g}$ of protein were incubated in $11-900 \mathrm{pM}^{125} \mathrm{I}-\alpha \mathrm{BTX}$ for $2.5 \mathrm{hr}$ at $22^{\circ} \mathrm{C}$. The saturation binding (top) and Scatchard curves (bottom) are the composite of 2 independent experiments (circles and triangles). Nonspecific binding was measured in the presence of $5 \mathrm{~mm}$ ACh. 


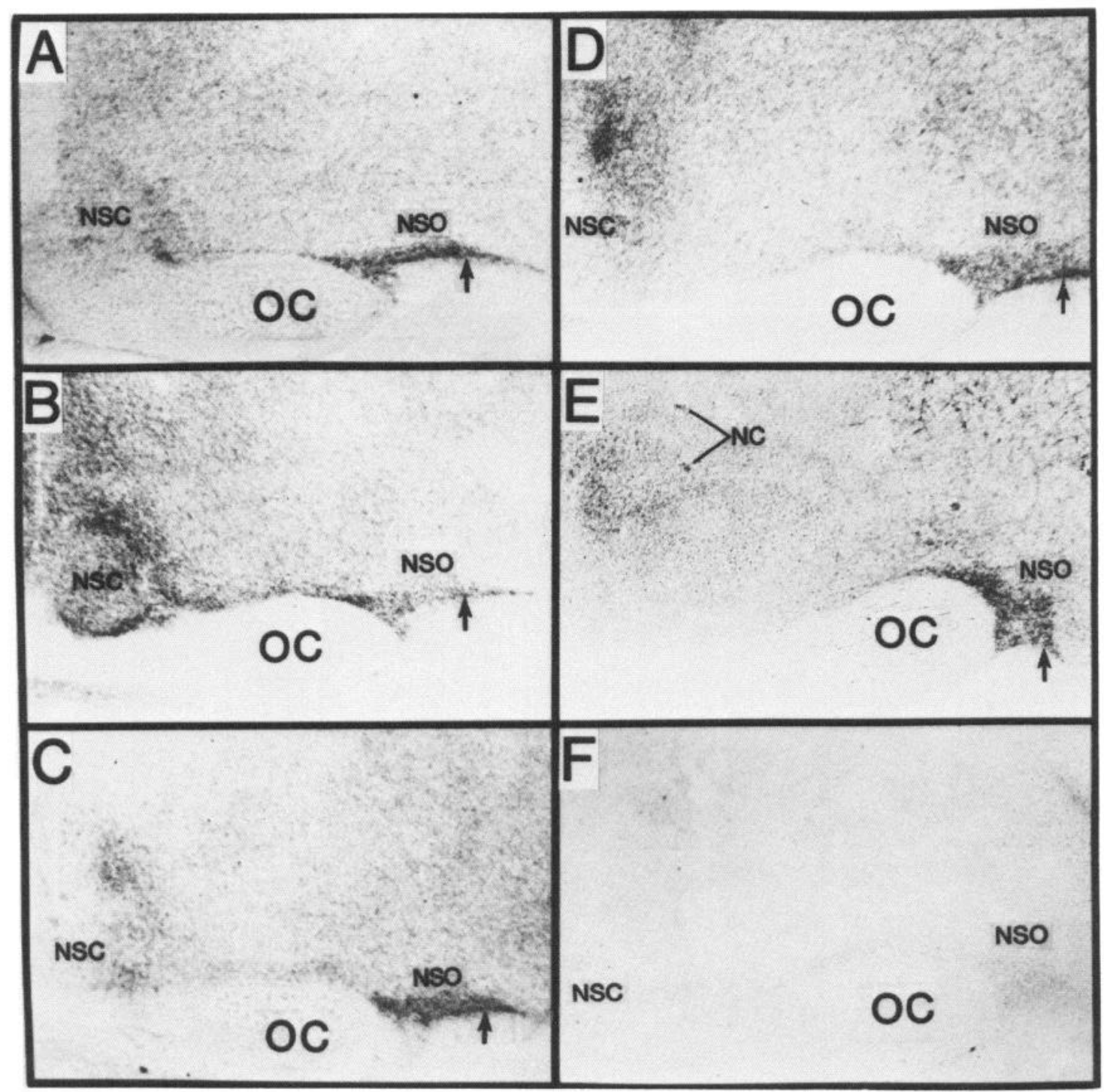

Figure 10. Distribution of high-affinity ${ }^{125} \mathrm{I}-\alpha \mathrm{BTX}$ binding sites in the rostral hypothalamus. $A-E$, Bright-field photomicrographs of uncounterstained $50 \mu \mathrm{m}$ sections illustrating the accumulation of silver grains after incubation in $54-111 \mathrm{pM}{ }^{125} \mathrm{I}-\alpha \mathrm{BTX}$ and processing for autoradiography. Sections were sampled at anterior-posterior coordinates of approximately A6400, A6200, A6100, A6000, A5800, and A5900 for $A-F$, respectively, according to the coordinate system of Konig and Klippel (1963). Arrow, High density of labeling along the base of the NSO. $F$, Nonspecific binding of ${ }^{125} \mathrm{I}-\alpha \mathrm{BTX}$. The section is lightly counterstained with Pyronin Y to illustrate the location of the various nuclei. Exposure time, $28 \mathrm{~d}$ at $4^{\circ} \mathrm{C}$. Magnification, $\sim 38 \times . N S O$, Supraoptic nucleus; $N C$, nucleus circularis complex; NSC, suprachiasmatic nucleus; $O C$, optic chiasm.

$26 \mathrm{~mm})>\mathrm{Li}^{+}(39 \mathrm{~mm})>\mathrm{K}^{+}(47 \mathrm{~mm})>\mathrm{Cs}^{+}(54 \mathrm{~mm})$. Concentrations of sucrose up to $150 \mathrm{~mm}$ had no effect on the binding of ${ }^{125} \mathrm{I}-\alpha \mathrm{BTX}$.

\section{Pharmacology of ${ }^{125} I-\alpha B T X$ binding}

The binding of a variety of ligands in competition with ${ }^{125} \mathrm{I}-$ $\alpha \mathrm{BTX}$ is summarized in Table 1 . The $K_{\mathrm{I}}$ for each compound was calculated according to Cheng and Prusoff (1973) from the concentration at which half-maximal inhibition of binding occurs $\left(I C_{50}\right)$. The most potent competitor was $\alpha \mathrm{BTX}$, followed by $d$-tubocurarine $>$ nicotine, dimethylphenylpiperazinium, and quinacrine $>$ ethopropazine, substance $\mathrm{P}$, butyrlcholine, and acetylcholine $>$ choline, arginine vasopressin, and phenylmethylsulfonyl fluoride. These data must be interpreted cautiously, however, since Hill analyses of the data for ACh, $\alpha$ BTX, $d$-tubocurarine, and dimethylphenylpiperazinium reveal slopes of $0.2-0.5$, indicating complex binding interactions. The complexity of the competition binding curve for $\mathrm{ACh}$ is illustrated in Figure 8. Hill analysis of the curve (Fig. 8, inset) yielded a slope of 0.2. A nonlinear regression analysis of the data indicates the presence of two binding sites. The high-affinity binding site (estimated $K_{\mathrm{I}}=3.6 \times 10^{-8} \mathrm{M}$ ) accounted for $31.4 \%$ of the total binding sites. The low-affinity binding site (estimated $K_{1}=7.4 \times$ $10^{-5} \mathrm{M}$ ) accounted for $68.6 \%$ of the total binding sites.

The competition binding of $\mathrm{ACh}$ in the presence of $150 \mathrm{~mm}$ $\mathrm{Na}^{+}$, where the ${ }^{125} \mathrm{I}-\alpha \mathrm{BTX}$ is interacting with a single site, reduced the complexity of the ACh binding profile. Inhibition of ${ }^{125} \mathrm{I}-\alpha \mathrm{BTX}$ binding in the $10^{-8}-10^{-6} \mathrm{M}$ range was lost, yielding a steeper curve with a Hill coefficient of 0.53 .

\section{Binding of ${ }^{125} I-\alpha B T X$ to hypothalamic sections from fixed brain}

Saturation binding and kinetic analyses of ${ }^{125} \mathrm{I}-\alpha \mathrm{BTX}$ binding to membranes prepared from $0.5 \%$ paraformaldehyde-fixed rat brain yielded results similar to those for unfixed membranes. The concentration-dependent accumulation of ${ }^{125}$ I- $\alpha$ BTX achieved by free-floating $50 \mu \mathrm{m}$ sections through the rostral hypothalamus of the fixed rat brain is illustrated in Figure 9. A 
NEUROPHYSIN
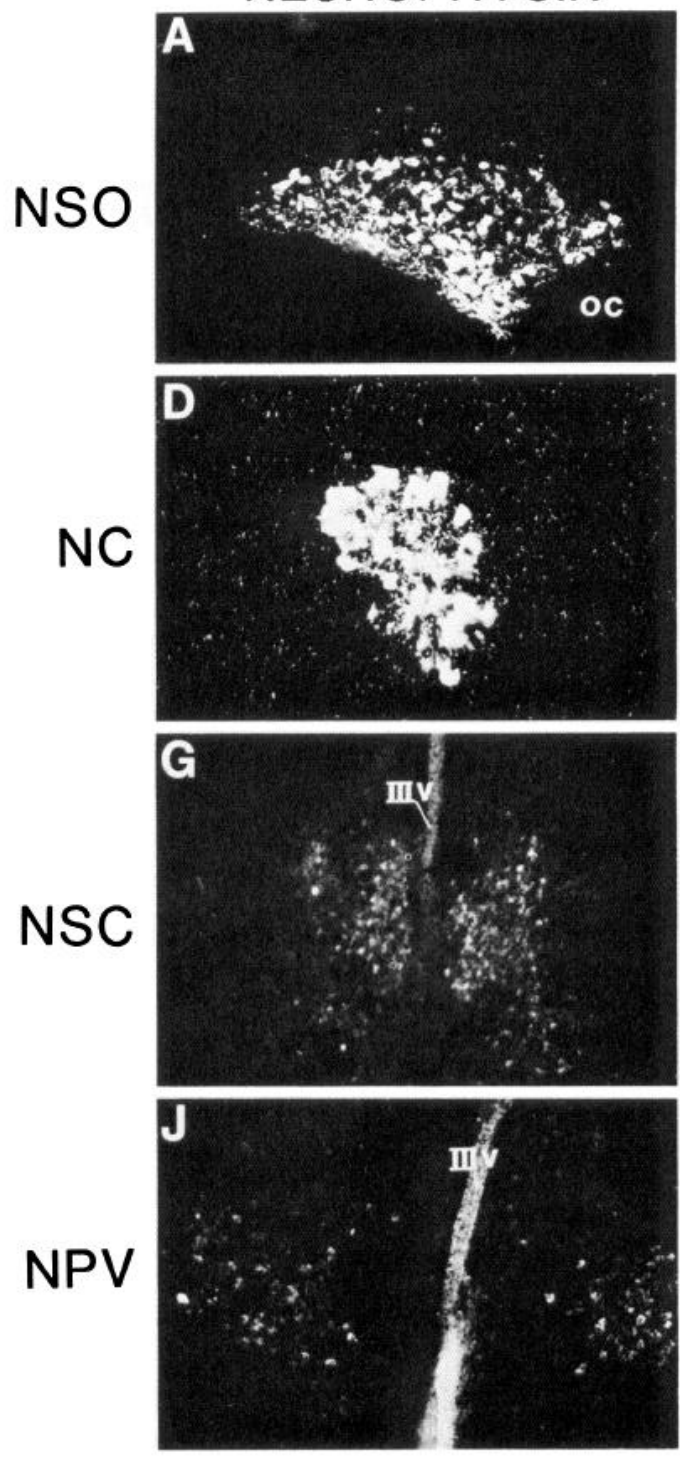

DARKFIELD
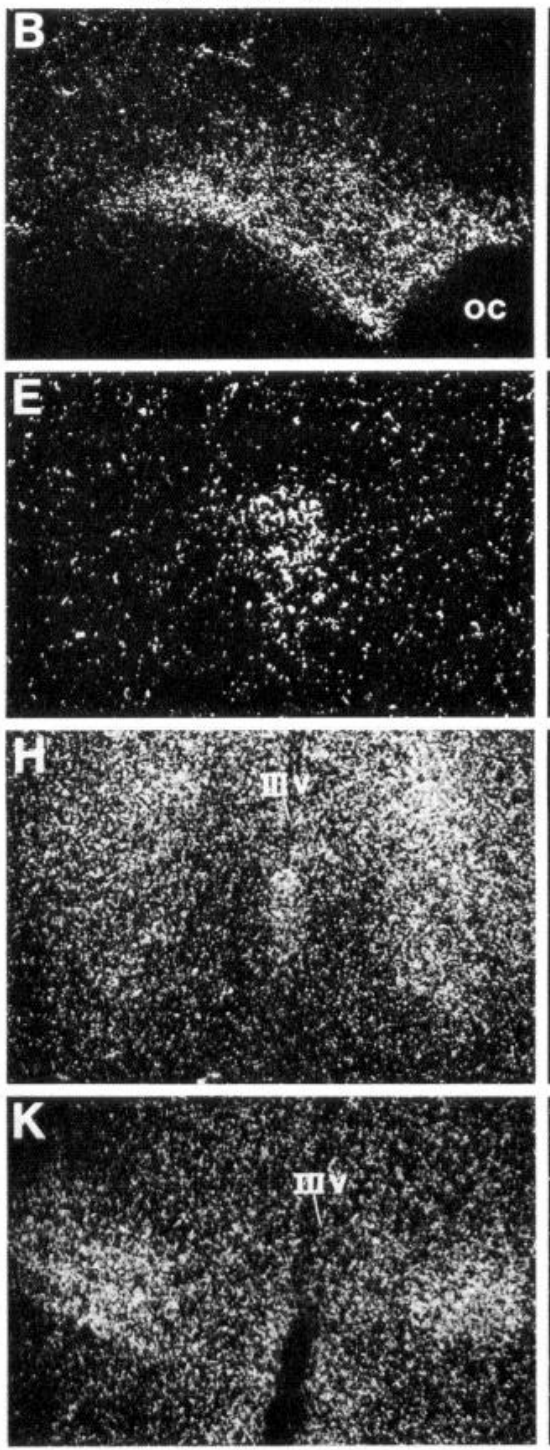

NON-SPECIFIC
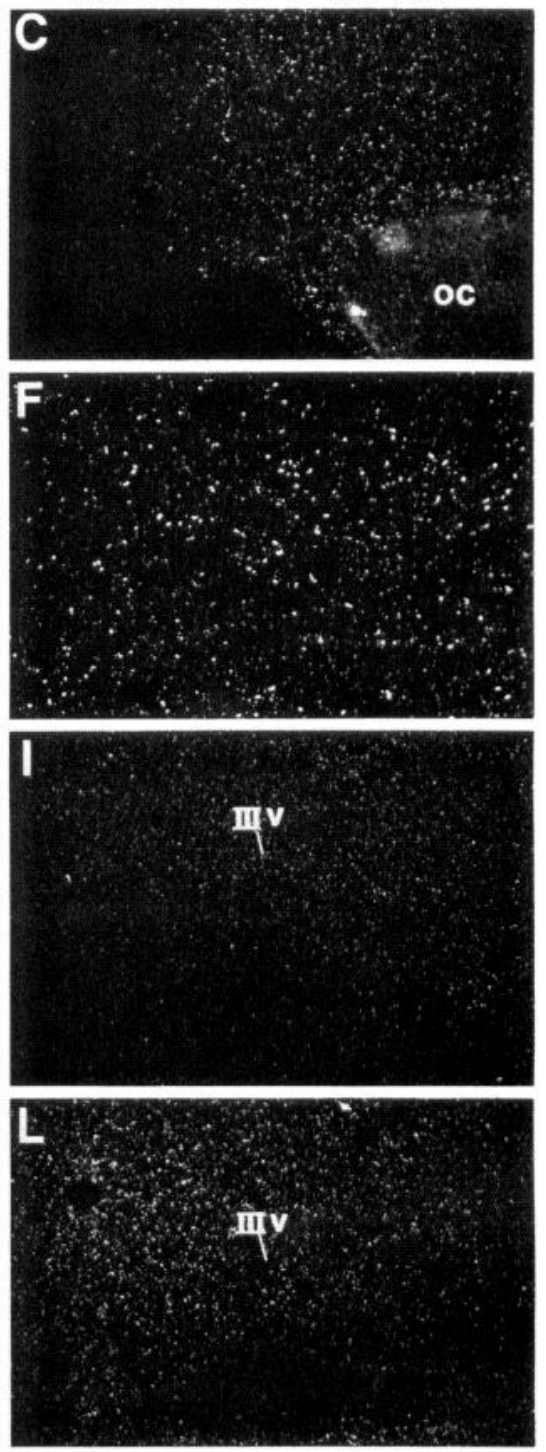

Figure 11. Distribution of ${ }^{125} \mathrm{I}-\alpha \mathrm{BTX}$ binding in relation to neurophysin-containing cells of the rostral hypothalamus. Hypothalamic sections were double-labeled by combining neurophysin immunocytochemistry with ${ }^{125} \mathrm{I}-\alpha \mathrm{BTX}$ binding under conditions optimal for both. NSO,NC, NSC, and $N P V$ labeled at ligand concentrations of $103,73,29$, and $111 \mathrm{pm}$, respectively. The first pair of photographs for each region $(A-B, D-E, G-H, J-$ $K$ ) represents the same section under $548 \mathrm{~nm}$ incident illumination, for visualization of the TRITC-GAR-neurophysin complex $(A, D$, $G, J)$, or under dark-field illumination for visualization of the overlying silver grains $(B, E, H, K)$. Nonspecific binding of ${ }^{125}$ I- $\alpha \mathrm{BTX}$ for the same region and concentration was determined on a separate section and is illustrated in the dark-field photomicrographs on the right $(C, F, I, L)$. Exposure time, $14 \mathrm{~d}$ at $4^{\circ} \mathrm{C}$. Magnification, $\sim 150 \times$ for NSO, NC, and NPV; $375 \times$ for NSC. NPV, Paraventricular nucleus; IIIV, third ventricle; other abbreviations as in Figure 10.

Scatchard analysis (Fig. 9, bottom) clearly illustrates the presence of 2 binding components. Dissociation constants of $1.7 \times$ $10^{-11}$ and $2.0 \times 10^{-10} \mathrm{M}$ were calculated for the high- and lowaffinity interactions, respectively. The density of the high-affinity site was approximately $1.6 \mathrm{fmol} / \mathrm{section}$, while the density of the low-affinity site was approximately $6.1 \mathrm{fmol} / \mathrm{section}$.

\section{Distribution of high-affinity ${ }^{125} I-\alpha B T X$ binding sites in rat hypothalamus}

The hypothalamic distribution of ${ }^{125} \mathrm{I}-\alpha \mathrm{BTX}$ binding at concentrations that predominantly label the high-affinity site is shown in Figure 10 . The accumulation of ${ }^{125} \mathrm{I}-\alpha \mathrm{BTX}$ is highly selective for the region of the NSO, NSC, and the NC. Weaker labeling occurs in the NPV, and some scattered diffuse labeling in the lateral and anterior dorsal hypothalamus. We observed no con- sistent, anatomically discrete distribution of ${ }^{125} \mathrm{I}-\alpha \mathrm{BTX}$ that correlated with low- and very-low-affinity binding sites.

The close association of high-affinity ${ }^{125} \mathrm{I}-\alpha \mathrm{BTX}$ binding with neuroendocrine cells is illustrated by the high correlation between the distribution of autoradiographic silver grains and neurophysin-immunoreactive cells on the same section. Examples of the distribution of ${ }^{125} \mathrm{I}-\alpha \mathrm{BTX}$ in relation to neurophysinimmunoreactive cells for the NSO, NC, NSC, and NPV are given in Figure 11. Within the NSO (Fig. 11, $A-C$ ), silver grains were found to be distributed across all neurophysin-immunoreactive cells. The highest density of grains was found to be localized to the ventral dendritic neuropil of the NSO, a region replete with immunofluorescent varicosities thought to be dendrites of the vasopressin and oxytocin magnocellular neurons (Armstrong et al., 1982). Grain density diminished sharply over 
the glial cell layer along the basal lamina, in which few or no immunofluorescent varicosities were observed.

The NC (Fig. 11, D-F) and magnocellular portions of the posterior lateral, anterior, and periventricular NPV (Fig. 11, $G-$ I) were similar to the NSO, with silver grains appearing over the immunofluorescent cell bodies and processes. The density of grains in the core of the NC was as high as in the NSO, whereas the density in the NPV was much less. In contrast to the above, the binding of ${ }^{125} \mathrm{I}-\alpha \mathrm{BTX}$ in the NSC did not overlap with the neurophysin-immunoreactive cell bodies (Fig. 11, G$I$ ). The perimeter of the NSC was generally labeled, leaving the immunofluorescent cell bodies in the medial portion of the NSC unlabeled.

\section{Discussion}

As many as 3 different sites can be identified for the binding of ${ }^{125} \mathrm{I}-\alpha \mathrm{BTX}$ to rat hypothalamus and brain stem membranes on the basis of differing affinities and kinetic properties. Each of these sites corresponds to an $\alpha$ BTX binding site that has been described previously. Saturation binding experiments by Schmidt (1977) and kinetically determined affinities by Lukas (1984b) have yielded $K_{\mathrm{d}} \mathrm{s}$ of 4-5 $\times 10^{-11} \mathrm{M}$. Salvaterra et al. (1975) and Lukas (1984b) have observed both high- and low-affinity binding sites in the same preparations with $K_{d} \mathrm{~s}$ of $0.9-5 \times 10^{-9} \mathrm{M}$ and 1-40 $\times 10^{-8} \mathrm{M}$, respectively, for the high- and low-affinity sites. Other investigators have reported single affinities of

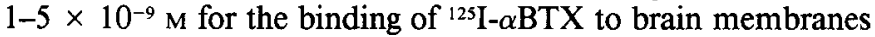
(Lukas, 1984a; Patrick and Stallcup, 1977b; Salvaterra et al., 1975). Failure to observe more than one binding site can often be attributed to the use of a restricted range of ligand concentrations or to the cation concentration of the binding buffer.

The significance of each type of ${ }^{125} \mathrm{I}-\alpha \mathrm{BTX}$ binding remains to be determined, but a substantial body of existing data indicates that ${ }^{125}$ I- $\alpha$ BTX binds with high affinity to a nicotinic cholinergic receptor-like polypeptide in rat brain. This binding is (1) on synaptosomes (Salvaterra et al., 1975), (2) associated with a protein with hydrodynamic properties and an isoelectric point similar to Torpedo nicotinic receptors (Lowy et al., 1976; Salvaterra and Mahler, 1976), (3) localized to the postsynaptic membrane (Hunt and Schmidt, 1978a; Lentz and Chester, 1977; Smolen, 1983; Vogel et al., 1977), (4) nonuniformly distributed in brain (Hunt and Schmidt, 1978b; Marks and Collins, 1982; Morley et al., 1977; Polz-Tejera et al., 1975; Segal et al., 1978; Silver and Billiar, 1976), and (5) ablc, in some cases, to be immunoprecipitated by antibodies to the purified nicotinic cholinergic receptor (Block and Billiar, 1979; Conti-Tronconi et al., 1985; Dolly and Barnard, 1984).

The binding of various drugs in competition with ${ }^{125} \mathrm{I}-\alpha \mathrm{BTX}$ is also consistent with that expected for a nicotinic cholincrgic receptor, with $d$-tubocurarine, nicotine, and dimethylphenylpiperazinium inhibiting the binding of ${ }^{125} I-\alpha B T X$ at relatively low concentrations. Each compound interacted with both the high- and low-affinity ${ }^{125} \mathrm{I}-\alpha \mathrm{BTX}$ binding sites. Inhibition of binding by $\mathrm{ACh}$ was particularly complex, as is illustrated by the heterogeneity of the competition curve. The shallow slope of the competition curve indicates that $\mathrm{ACh}$ recognizes 2 binding sites, with estimated affinities of $3.6 \times 10^{-8} \mathrm{M}$ and $7.4 \times$ $10^{-5} \mathrm{M}$. Computer analysis of the ACh competition binding curve indicated that $31.4 \%$ of the total binding sites corresponded to high-affinity $\mathrm{ACh}$ binding, whereas $68.6 \%$ of the binding sites were of low affinity. This distribution of high- and lowaffinity sites is similar to what would be predicted from the concentration of ${ }^{125} \mathrm{I}-\alpha \mathrm{BTX}$ (517 pM) used in the assay, given the $K_{\mathrm{d}}$ values obtained from the Scatchard analysis. Competition binding experiments in the presence of $150 \mathrm{mM} \mathrm{Na}^{+}$, where only a single ${ }^{125} \mathrm{I}-\alpha \mathrm{BTX}$ binding site can be discriminated, eliminated the high-affinity $\mathrm{ACh}$ interaction but increased the Hill slope only to a value of 0.53 , suggesting that $\mathrm{ACh}$ was still interacting at 2 sites. Thus, it would appear that the high-affinity $\mathrm{ACh}$ binding may have corresponded to a low-affinity ${ }^{125} \mathrm{I}-\alpha \mathrm{BTX}$ binding site and that the heterogeneous $\mathrm{ACh}$ binding reflected in the competition curve was not simply a function of the complexity of the ${ }^{125} \mathrm{I}-\alpha \mathrm{BTX}$ interaction.

Evidence indicating that several polypeptides in the CNS bind cholinergic ligands and that substantial variation may exist between different types of tissue has been accumulating over the past several years. For example, multiple nicotinic cholinergiclike binding sites have been reported for ${ }^{3} \mathrm{H}$-nicotine (Romano and Goldstein, 1980), ${ }^{3} \mathrm{H}$-dihydro- $\beta$-erythrodine (Williams and Robinson, 1984), as well as ${ }^{125}$ I- $\alpha$ BTX (Lukas, 1984b; Salvaterra et al., 1975; Yazulla and Schmidt, 1977). Only a single binding site has been reported for ${ }^{3} \mathrm{H}-\mathrm{ACh}$ (Schwartz et al., 1982), but a site with a $K_{\mathrm{d}}$ greater than $10^{-8} \mathrm{M}$ could not have been measured because of high nonspecific binding. More biochemical characterization is needed to clearly evaluate the significance and interrelationships of each of these binding sites. Our data, indicating that ${ }^{125} \mathrm{I}-\alpha \mathrm{BTX}$ can bind specifically to 3 different binding sites in rat brain, compare favorably with the observation of Betz et al. (1982) that ${ }^{125}$ I- $\alpha$ BTX binds to 3 different polypeptides isolated from chick retina. Only 1 of these polypeptides was similar in size to purified $n A C h R$. The protein from rat brain that binds ${ }^{125} \mathrm{I}-\alpha \mathrm{BTX}$ can be $75 \%$ precipitated by antibodies to muscle $\mathrm{nAChR}$, but not by antibodies to Torpedo nAChR (Mills and Wonnacott, 1984). Recently, Conti-Tronconi et al. (1985) have demonstrated an ACh receptor from chick brain that is homologous, but not identical, to the muscle nicotinic ACh receptor.

The binding of ${ }^{125} \mathrm{I}-\alpha \mathrm{BTX}$ to rat brain membranes is highly sensitive to the $\mathrm{Na}^{+}$concentration in the buffer. The sharp decline in binding as the buffer $\mathrm{Na}^{+}$concentration increases appears to be due to a decrease in the affinity of the ${ }^{125} \mathrm{I}-\alpha \mathrm{BTX}$ for the high-aflinity binding site, and possibly to a loss of the lowaffinity binding site. All monovalent cations decrease the binding of ${ }^{125}$ I- $\alpha$ BTX, indicating a general lack of cation specificity. The order of potency of the various cations does not predict a simple interaction of $\alpha \mathrm{BTX}$ with the $\mathrm{Na}^{+}$channel. The significance of this cation sensitivity remains to be determined.

To better understand the relationship between the vasopressin/oxytocin neuroendocrine system and its stimulation by putative nicotinic cholinergic input, we have assessed the binding of ${ }^{125} \mathrm{I}-\alpha \mathrm{BTX}$ to free-floating sections of $0.5 \%$ paraformaldehyde-fixed hypothalamus under conditions that allow doublelabeling with an immunocytochemical probe. With this approach, it is clear that high-affinity binding sites for ${ }^{125} \mathrm{I}-\alpha \mathrm{BTX}$ are concentrated in the region of the NSO, NC, NPV, and NSC. Of these regions, the NSO contains the most striking concentration of ${ }^{125} \mathrm{I}-\alpha \mathrm{BTX}$ binding sites. The binding overlaps greatly with the localization of neurophysin-immunofluorescent perikarya, particularly the ventral neuropil, which contains a dense network of dendrite-like processes extending from the vasopressin and oxytocin neurons of the NSO (Armstrong et al., 1982; Yulis et al., 1984). These processes form a bundle that is sandwiched between the magnocellular perikarya of the NSO and a thin glial cushion that, along with the basal lamina, makes up the ventral surface of the brain. A high density of synaptic contacts (Armstrong et al., 1982) and catecholamine varicosities (McNeill and Sladek, 1980) within the ventral neuropil, as compared to that in the NSO (Leranth et al., 1975), suggests that much of the synaptic input to the cells of the NSO is mediated by contacts within the ventral neuropil. Many of the presynaptic terminals found contacting these processes contain round, clear vesicles similar to cholinergic endings (Yulis et al., 1984).

A similar pattern of binding was apparent in the $\mathrm{NC}$ and NPV. The small groups of magnocellular neurons making up the $\mathrm{NC}$ contain either vasopressin or oxytocin (Rhodes et al., 1981) and are organized in a circular fashion around blood 
vessels, with bundles of immunoreactive fibers following the vessel in the core of the nucleus. The present data helped to establish the $\mathrm{NC}$ as a possible primary target for cholinergic control of vasopressin/oxytocin secretion. The magnocellular neurons of the NPV also bound ${ }^{125}$ I- $\alpha$ BTX but appeared to have a lower density of sites than those of the NSO or NC. Again, though, binding was associated exclusively with the regions of the NPV that contained neurophysin-immunoreactive cell bodies.

The parvocellular vasopressin-containing cells of the NSC were a contrast to the magnocellular neurons of the NSO, NC and NPV. Although a relatively high concentration of binding sites was present in the region surrounding the NSC, little or no overlap with neurophysin-immunoreactive cell bodies was observed. Vasopressin fibers projecting dorsally from the NSC (Sofroniew and Weindl, 1978) or dendrites extending laterally from the ventral NSC (Stephan et al., 1981; van den Pol, 1980) could be a potential target for cholinergic input. Assessment of this pussibility will require closer examination of the ${ }^{125} \mathrm{I}-\alpha \mathrm{BTX}$ binding site within this region. Some support for an interaction of a putative nicotinic cholinergic receptor with the NSC has been provided by the observation that $\alpha \mathrm{BTX}$, applied locally to the region of the NSC, blocks the effects of light or cholinergic stimulation on serotonin- $N$-acetyltransferase activity in the pineal (Zatz and Brownstein, 1981).

Within the rostral hypothalamus, the magnocellular, neuroendocrine cells of the NSO, NC, and NPV are associated with the highest density of high-affinity ${ }^{125} \mathrm{I}-\alpha \mathrm{BTX}$ binding sites. The reason for this association is presently unknown but may reflect input from a nicotinic cholinergic system that is thought to control the release of vasopressin. Our findings supplement the recent work of Mason (1985), which illustrates staining of the NSO with a monoclonal antibody to the alpha subunit of the nicotinic cholinergic receptor of electric eel. The hypothalamic neuroendocrine system may be a model system for the clarification of the significance of the $\alpha$ BTX binding site in brain, as well as for the understanding of the control of vasopressin secretion.

\section{References}

Armstrong, W. E., J. Scholer, and T. McNeill (1982) Immunocytochemical, golgi and electron microscopic characterization of putative dendrites in the ventral glial lamina of the rat supraoptic nucleus. Ncuroscience 7: 679-694.

Arnauld, E., M. Cirino, B. S. Layton, and L. P. Renaud (1983) Contrasting actions of amino acids, acetylcholine, noradrenaline and leucine enkephalin on the excitability of supraoplic vasopressin-secreting neurons. Neuroendocrinology 36: 187-196.

Barker, J. L., J. W. Crayton, and R. A. Nicoll (1971) Noradrenaline and acetylcholine responses of supraoptic neurosecretory cells. J. Physiol. (Lond.) 218: 19-32.

Betz, H., D. Graham, and H. Rehm (1982) Identification of polypeptides associated with a putative neuronal nicotinic acetylcholine receptor. J. Biol. Chem. 257: 11,390-11,394.

Bioulac, B., O. Gaffori, M. Harris, and J.-D. Vincent (1978) Effects of acetylcholine, sodium glutamate and GABA on the discharge of supraoptic neurons in the rat. Brain Res. 154: 159-162.

Block, G. A., and R. B. Billiar (1979) Immunologic similarities between the hypothalamic $\alpha$-bungarotoxin receptor and the Torpedo californica nicotinic cholinergic receptor. Brain Res. 178: 381-387.

Carbonetto, S. T., D. M. Fambrough, and K. J. Muller (1978) Nonequivalence of $\alpha$-bungarotoxin receptors and acetylcholine receptors in chick sympathetic neurons. Proc. Natl. Acad. Sci. USA 75: 10161020 .

Chalazonitis, A., L. A. Greene, and M. Nirenberg (1974) Electrophysiological characteristics of chick embryo sympathetic neurons in dissociated cell culture. Brain Res. 68: 235-252.

Cheng, Y.-C., and W. H. Prusoff (1973) Relationship between the inhibition constant $\left(K_{\mathrm{i}}\right)$ and the concen tration of inhibitor which causes 50 percent inhibition $\left(I_{50}\right)$ of an enzymatic reaction. Biochem. Pharmacol. 22: 3099-3108.
Chou, T. C., and C. T. Lee (1969) Effect of whole and fractionated cobra venom on sympathetic ganglionic transmission. Eur. J. Pharmacol. 8: 326-330.

Conti-Tronconi, B. M., S. M. J. Dunn, E. A. Barnard, J. O. Dolly, F. A. Lai, N. Ray, and M. Raftery (1985) Brain and muscle nicotinic acetylcholine receptors are different but homologous proteins. Proc. Natl. Acad. Sci. USA 82: 5208-5212.

Dolly, J. O., and E. A. Barnard (1984) Nicotinic acetylcholine receptors: An overview. Biochem. Pharmacol. 33: 841-858.

Duggan, A. W., J. G. Hall, and C. Y. Lee (1976) Alpha-bungarotoxin, cobra neurotoxin and excitation of Renshaw cells by acetylcholine. Brain Res. 107: 166-170.

Gahwiler, B. H., and J. J. Dreifuss (1980) Transition from random to phasic firing induced in neurons cultured from the hypothalamic supraoptic area. Brain Res. 193: 415-425.

Greene, L. A., A. J. Sytkowski, Z. Vogel, and M. Nirenberg (1973) $\alpha$-Bungarotoxin used as a probe for acetylcholine receptors of cultured neurones. Nature 243: 163-166.

Harden, T. K., R. B. Meeker, and M. W. Martin (1983) Interaction of a radiolabeled agonist with cardiac muscarinic cholinergic receptors. J. Pharmacol. Exp. Ther. 227: 570-577.

Hayward, J. N., T. A. Reaves, Jr., R. S. Greenwood, and R. B. Meeker (1983) Neuroendocrine cells in vitro: Electrophysiology, triple labeling with dye marking, immunocytochemical and ultrastructural analysis and hormone release. In Methods in Enzymology, Vol. 103, Hormone Action, Pt. H, P. M. Conn, ed., pp. 132-147, Academic, New York.

Hunt, S. P., and J. Schmidt (1978a) The electron microscopic autoradiographic localization of $\alpha$-bungarotoxin binding sites within the central nervous system of the rat. Brain Res. 142: 152-159.

Hunt, S. P., and J. Schmidt (1978b) Some observations on the binding patterns of $\alpha$-bungarotoxin in the central nervous system of the rat. Brain Res. 157: 213-232.

König, J. F. R., and R. A. Klippel (1963) The Rat Brain. A Stereotaxic Atlas of the Forebrain and Lower Parts of the Brain Stem. Krieger, New York.

Lentz, T. L., and J. Chester (1977) Localization of acetylcholine reccptors in central synapses. J. Ccll Biol. 75: 258-267.

Leranth, C., L. Zaborszky, J. Marton, and M. Palkovits (1975) Quantitative studies on the supraoptic nucleus in the rat. I. Synaptic organization. Exp. Brain Res. 22: 509-523.

Lowry, O. H., N. H. Rosebrough, A. C. Farr, and R. J. Randall (1951) Protein measurement with Folin phenol reagent. J. Biol. Chem. 193: 265-275.

Lowy, J., J. McGregor, J. Rosenstone, and J. Schmidt (1976) Solubilization of an $\alpha$-bungarotoxin-binding component from rat brain. Biochemistry 15: 1522-1527.

Lukas, R. J. (1984a) Properties of curaremimetic neurotoxin binding sites in the rat central nervous system. Biochemistry 23: 1152-1160.

Lukas, R. J. (1984b) Detection of low affinity $\alpha$-bungarotoxin binding sites in the rat central nervous system. Biochemistry 23: 1160-1164.

Marks, M. J., and A. C. Collins (1982) Charactcrization of nicotinc binding in mouse brain and comparison with the binding of $\alpha$-bungarotoxin and quinuclidinyl benzilate. Mol. Pharmacol. 22: 554-564.

Marshall, L. M. (1981) Synaptic localization of $\alpha$-bungarotoxin binding which blocks nicotinic transmission at frog sympathetic neurons. Proc. Natl. Acad. Sci. USA 78: 1948-1952.

Mason, W. T. (1985) Staining of the magnocellular nuclei of the rat hypothalamus by a monoclonal antibody directed against the $\alpha$-subunit of the nicotinic cholinergic receptor. Neurosci. Lett. 59: 89-95.

McNeill, T. H., and J. R. Sladek, Jr. (1980) Simultaneous monoamine histofluorescence and neuropeptide immunocytochemistry: II. Correlative distribution of catecholamine varicosities and magnocellular neurosecretory neurons in the rat supraoptic and paraventricular nuclei. J. Comp. Neurol. 193: 1023-1033.

Meeker, R. B., K. M. Michels, M. T. Libber, and J. N. Hayward (1984) Distribution of putative nicotinic cholinergic receptors within the supraoptic nucleus of the rat hypothalamus. Soc. Neurosci. Abstr. 10: 89.

Mills, A., and S. Wonnacott (1984) Antibodies to nicotinic acetylcholine receptors used to probe the structural relationships between brain $\alpha$-bungarotoxin binding sites and nicotinic receptors. Neurochem. Int. 6: 249-257.

Morley, B. J. (1981) The properties of brain nicotine receptors. Pharmacol. Ther. 15: 111-122.

Morley, B. J., J. F. Lorden, G. B. Brown, G. E. Kemp, and R. J. Bradley 
(1977) Regional distribution of nicotinic acetylcholine receptor in rat brain. Brain Res. 134: 161-166.

Morley, B. J., G. R. Farley, and E. Javel (1983) Nicotinic acetylcholine receptors in mammalian brain. TIPS 4: 225-227.

Oswald, R. E., and J. A. Freeman (1981) Alpha-bungarotoxin binding and central nervous system nicotinic acetylcholine receptors. Neuroscience $6: 1-14$.

Patrick, J., and W. B. Stallcup (1977a) $\alpha$-Bungarotoxin binding and cholinergic receptor function on a rat sympathetic nerve line. J. Biol. Chem. 252: 8629-8633.

Patrick, J., and W. B. Stallcup (1977b) Immunological distinction between acetylcholine receptor and the $\alpha$-bungarotoxin-binding component on sympathetic neurons. Proc. Natl. Acad. Sci. USA 74:46894692.

Polz-Tejera, G., J. Schmidt, and H. J. Karten (1975) Autoradiographic localisation of $\alpha$-bungarotoxin binding sites in the central nervous system. Nature 258: 349-351.

Reaves, T. A., Jr., A. Hou-Yu, E. A. Zimmerman, and J. N. Hayward (1983) Supraoptic neurons in the rat hypothalamo-neurohypophysial explant: Double labeling with lucifer yellow injection and immunocytochemical identification of vasopressin- and neurophysin-containing neuroendocrine cells. Neurosci. Lett. 37: 137-142.

Rhodes, C. H., J. I. Morrell, and D. W. Pfaff (1981) Immunohistochemical analysis of magnocellular elements in rat hypothalamus: Distribution and number of cells containing neurophysin, oxytocin and vasopressin. J. Comp. Neurol. 198: 45-64.

Romano, C., and A. Goldstein (1980) Stereospecific nicotine receptors on rat brain membranes. Science 210: 647-650.

Sakai, K. K., B. H. Marks, J. M. George, and A. Koestner (1974) The isolated organ-cultured supraoptic nucleus as a neuropharmacological test system. J. Pharmacol. Exp. Ther. 190: 482-491.

Salvaterra, P. M., and H. R. Mahler (1976) Nicotinic acetylcholine receptor from rat brain. J. Biol. Chem. 251: 6327-6334.

Salvaterra, P. M., H. R. Mahler, and W. J. Moore (1975) Subcellular and regional distribution of ${ }^{125}$ I-labeled $\alpha$-bungarotoxin binding in rat brain and its relationship to acetylcholinesterase and choline acetyltransferase. J. Biol. Chem. 250: 6469-6475.

Schmidt, J. (1977) Drug binding properties of an $\alpha$-bungarotoxinbinding component from rat brain. Mol. Pharmacol. 13: 283-290.

Schwartz, R. D., R. McGee, Jr., and K. J. Kellar (1982) Nicotinic cholinergic receptors labeled by $\left[{ }^{3} \mathrm{H}\right]$ acetylcholine in rat brain. Mol. Pharmacol. 22: 56-62.

Segal, M., Y. Dudai, and A. Amsterdam (1978) Distribution of an $\alpha$-bungarotoxin-binding cholinergic nicotinic receptor in rat brain. Brain Res. 148: 105-119.
Silver, J., and R. B. Billiar (1976) An autoradiographic analysis of $[3 \mathrm{H}] \alpha$-bungarotoxin distribution in the rat brain after intraventricular injection. J. Cell Biol. 71: 956-963.

Sladek, C. D. (1983) Regulation of vasopressin release by neurotransmitters, neuropeptides and osmotic stimuli. In The Neurohypophysis: Structure, Function and Control, Progress in Brain Research, Vol. 60, B. A. Cross and G. Leng, eds., pp. 71-90, Elsevier, New York.

Smolen, A. J. (1983) Specific binding of $\alpha$-bungarotoxin to synaptic membranes in rat sympathetic ganglion: Computer best-fit analysis of electron microscope radioautographs. Brain Res. 289: 177-188.

Sofroniew, M. V., and A. Weindl (1978) Projections from the parvocellular vasopressin- and neurophysin-containing neurons of the suprachiasmatic nucleus. Am. J. Anat. 153: 391-430.

Sokol, H. W., E. A. Zimmerman, W. II. Sawyer, and A. G. Robinson (1976) The hypothalamic-neurohypophysial system of the rat: Localization and quantitation of neurophysin by light microscopic immunocytochemistry in normal rats and in brattleboro rats deficient in vasopressin and a neurophysin. Endocrinology 98: 1176-1188.

Stephan, F. K., K. J. Berkley, and R. L. Moss (1981) Efferent connections of the rat suprachiasmatic nucleus. Neuroscience 6: 26252641.

van den Pol, A. N. (1980) The hypothalamic suprachiasmatic nucleus of rat: Intrinsic anatomy. J. Comp. Neurol. 191: 661-702.

Vogel, Z., G. J. Maloney, A. Ling, and M. P. Daniels (1977) Identification of synaptic acetylcholine receptor sites in retina with peroxidase-labeled $\alpha$-bungarotoxin. Proc. Natl. Acad. Sci. USA 74: 32683272.

Volle, R. L., and G. B. Koelle (1975) Ganglionic stimulating and blocking agents. In The Pharmacological Basis of Therapeutics, L. S. Goodman and A. Gilman, eds., pp. 565-574, Macmillan, New York. Wang, G.-K., S. Molinaro, and J. Schmidt (1978) Ligand responses of $\alpha$-bungarotoxin binding sites from skeletal muscle and optic lobe of the chick. J. Biol. Chem. 253: 8507-8512.

Williams, M., and J. L. Robinson (1984) Binding of the nicotinic cholinergic antagonist, dihydro- $\beta$-erythroidine, to rat brain tissue. J. Neurosci. 4: 2906-2911.

Yazulla, S., and J. Schmidt (1977) Two types of receptors for $\alpha$-bungarotoxin in the synaptic layers of the pigeon retina. Brain Res. 138: 45-57.

Yulis, C. R., B. Peruzzo, and E. M. Rodriquez (1984) Immunocytochemistry and ultrastructure of the neuropil located ventral to the rat supraoptic nucleus. Cell Tissue Res. 236: 171-180.

Zatz, M., and M. J. Brownstein (1981) Injection of $\alpha$-bungarotoxin near the suprachiasmatic nucleus blocks the effects of light on nocturnal pineal enzyme activity. Brain Res. 213: 438-442. 